\title{
Japan moves gingerly towards guidelines on gene therapy
}

Tokyo. Japan took its first step towards gene therapy last week when a committee of the Ministry of Health and Welfare (MHW) recommended the establishment of guidelines and the creation of a central committee to review research and clinical trials involving humans. But, although Japanese medical researchers are eager to follow the lead of the United States in this field, the Japanese must overcome fundamental weaknesses in the system of reviewing recombinant DNA research before they can begin gene therapy.

In bureaucratic Japan, there are almost as many guidelines and committees for recombinant DNA research as there are government ministries and agencies. The Ministry of Education, Science and Culture (MESC) has a committee to review proposals from universities, while the Science and Technology Agency (STA) has a parallel committee to deal with all other national research laboratories. On top of this, the health ministry, the Ministry of International Trade and Industry and the Ministry of Agriculture, Forestry and Fisheries each have guidelines for industrial applications that fall within their respective territories.

None of these committees or guidelines has so far addressed gene transfer in humans because the issue has been considered "taboo", says Mitsuru Miyata, editor of the influential newsletter Nikkei Biotechnology. But pressure from the medical research community and the pharmaceutical industry, combined with last week's announcement by the health ministry, is expected to spur action by other government agencies.

The government bodies dealing with health, science and education all play an important role in clinical applications of the technique. MHW oversees drug companies, hospitals and most medical research insti- tutes, MESC is responsible for university hospitals and STA approves recombinant DNA research in all national research laboratories outside the universities. Despite their interest, it is not obvious what should happen next.

MHW officials say they have "no clear idea" of the form the proposed committee or guidelines should take and that their proposal is intended to "stimulate discussion". However, the MHW committee report calls for a group comparable to the Recombinant DNA Advisory Committee in the United States. Miyata and others say that MHW would expect to be in charge of establishing guidelines for commercial medical applications of gene therapy.

Quite apart from these bureaucratic turf wars, supporters of gene therapy must also cope with a lack of adequate systems for review of clinical applications of gene therapy at medical research institutions. Hospitals and medical research institutes have internal review boards to screen the safety, ethics and efficacy of new medical techniques. But the composition and effectiveness of these committees varies greatly from institution to institution, says Masanori Fukushima of Aichi Cancer Centre, a vocal critic of clinical research in Japan.

Some review boards contain experts from science and the law as well as members of the public. But many consist solely of members of the institute, who may not understand the role they are supposed to play, according to Fukushima, and who seldom stay in touch with medical experiments they have approved. Before guidelines for gene therapy are designed, he says, Japan needs rules for the establishment of institutional review boards.

There is also the question of why Japan should do gene therapy at all. Medical researchers want to use it to catch up with the frontiers of science, but Fukushima warns that the scientific basis of gene therapy in Japan is "weak and thin" and that Japanese physicians "lack a clear strategy" for applying the technique.

The movement towards gene therapy highlights the problems that Japan faces in handling the ethical, social and legal issues arising from genetic research. The government invests a tiny amount in these issues compared with what is spent in the United States, Europe, Canada and Australia. Japan has few lawyers, ethicists or social scientists familiar with the rapidly evolving field, says Miyata, and those who do take an interest are "extremely conservative".

The health ministry intends to produce more detailed guidelines by the end of the year. In the meantime, the reactions of other government ministries and agencies to the preliminary plan is eagerly awaited.

David Swinbanks

\section{French AIDS scandal goes to court}

Four former French health officials went on trial last week in Paris on charges that they knowingly authorized the distribution of blood infected with the human immunodeficiency virus (HIV) in 1985. The scandal threatens to expand to other French political figures and could even touch on the continuing dispute between the United States and France over the discovery of HIV.

The officials are charged with allowing contaminated and unscreened blood to be used for five months after screening tests were available. A government investigation concluded last year that the officials delayed the use of a US blood test until a test manufactured by Diagnostic Pasteur, the commercial arm of the Pasteur Institute, could be produced (see Nature 353, 197; 1991).

Lawyers for Robert Gallo, the US National Institutes of Health researcher who is in dispute with the Pasteur Institute over the discovery and patent ownership of the AIDS virus, say that the scandal shows that Pasteur scientists were not then as aware of the role of the AIDS virus as they now claim. François Gros, a former Pasteur director, was chairman of the meeting at which the decision was made to delay the test, and Luc Montagnier, the Pasteur researcher and codiscoverer of the virus, was also a government adviser. According to a transcript of an important meeting, French officials seem to have been advised wrongly that HIV did not appear to cause AIDS in most cases.

One of the officials now on trial, Michael Garretta, the former director of the national transfusion centre, has said that he and the other defendants are being made scapegoats and that the court should expand its investigation.

Christopher Anderson 